\begin{tabular}{|c|c|c|}
\hline$\infty$ & 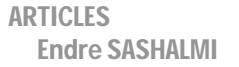 & 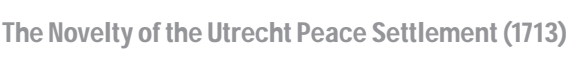 \\
\hline
\end{tabular}

\title{
The Novelty of the Utrecht Peace Settlement (1713)*
}

\author{
Endre SASHALMI
}

\author{
Középkori és Koraújkori Történeti Tanszék, Történettudományi Intézet \\ Bölcsészettudományi Kar, Pécsi Tudományegytelem \\ Department of Medieval and Early Modern History, Institute of History \\ Faculty of Humanities, University of Pécs \\ Rókus u. 2, H-7624 Pécs, Hungary \\ endresashalmi@gmail.com
}

\section{Exposition of the problem}

There is a well-established view in political parlance and in historiography as well which looks at the Peace of Westphalia (1648) as the turning point in international relations, marking the birth of the system of sovereign states in Europe, and of the "classical law of nations". ${ }^{1}$ In accordance with this view the term, 'Westphalian order' implies the "sovereignty and equality of states, the religious neutrality of the international order and the balance of power". ${ }^{2}$ This interpretation, however, has been seriously and convincingly challenged recently by historians and historians of international law alike. ${ }^{3}$ Randall Lesaffer, who belongs to the latter group, laconically states: "The truth is that none of these principles were introduced, or even appear as principles of international relations in the Westphalia Peace Treaties." 4 Modern historiography likewise argues, that the treaties of Muenster and Osnabrück, for there were the two towns in Westphalia where the negotiations were conducted due to the religious division, dealt not with the affairs of Europe but primarily with the affairs of the Empire, and the Westphalian Settlement was made in the spirit of tradition, and not of innovation. ${ }^{5}$ Peace was reached not by accepting new principles; on contrary, it was concluded through the revival of old ones which had been partly undermined by the long war. ${ }^{6}$ Territorial changes were, for example, justified by quoting hair-splitting dynastic rights, because it was not acceptable to base the transfer of territories on the right of con-

\footnotetext{
* The present scientific contribution is dedicated to the $650^{\text {th }}$ anniversary of the foundation of the University of Pécs

1 For the summary and criticism of this view see especially: LESAFFER, Randall: The Classical Law of Nations (1500-1800), in: Research Handbook on the Theory and History of International Law, ORAKHELASHVILI, Alexander (ed.), Cheltenham-Northampton 2011, 414.

2 LESAFFER, 414.

3 LESAFFER, 414; HÖBELT, Lothar: The Westphalian Peace: Augsburg Mark II or Celebrated Armistice?, in: The Holy Roman Empire 1495-1806, EVANS, Robert J. W. - WILSON, Peter H. (eds.), Leiden 2012, 19-34; OSIANDER, Andreas: The States System of Europe, Oxford 1994; STURDY, David J.: Fractured Europe 1600-1721, Oxford 2002, 70-75; BLACK, Jeremy: History of Diplomacy, London 2010, 64; WHALEY, Joachim: Germany and the Holy Roman Empire. Volume I: Maximilian to the Peace of Westphalia 1493-1648, Oxford $2012,619-632$.

4 LESAFFER, 414.

5 STURDY, 74.

6 Ibidem, 74.
} 
quest. ${ }^{7}$ Even the recognition of the independence of Switzerland and the United Provinces were not radically new steps according to Andreas Osiander - they proved to be such only in retrospect. ${ }^{8}$ This is true especially in the Swiss case which, on the one hand, could be treated as an affair of the Empire; on the other hand it is eloquent to keep in mind that "no more than the treaty of 1499 did the members of the Confederation regard the Peace of Westphalia as marking the formal end of their belonging to the Holy Roman Empire". 9 Moreover, it is crucial in the evaluation of the Westphalian Settlement that the terms liberty and safety of Europe, and balance of power were not used in the documents of these peace treaties; and when, on French initiative, the term sovereignty was proposed to be included in the treaties, it was definitely turned off. Indeed, "it was not the intention of those who framed the Peace of Westphalia to create a balance of power between sovereign states of Europe". ${ }^{10}$ We can, however, find these terms in the Utrecht Treaties! The nimbus of Westphalia can most probably be explained by the large number of participants there, but this, in turn, was the consequence of the fact that in one way or another all the major European powers were involved in the long war. ${ }^{11}$

According to David Sturdy's eloquent wording, Westphalia showed how a peace conference could, or rather, how it could not be managed: the two sites, the obsession with ceremonial concerning rank and precedence, the use of mediators (the pope's legate in Muenster, the king of Denmark in Osnabrück) were the most important obstacles to reach an agreement in a short time. ${ }^{12}$ Therefore, the lesson of Westphalia was twofold: negotiations should be held in one town, and the established order of diplomatic rank and precedence should be suspended during the negotiations. ${ }^{13}$ In the heart of this latter issue lay the commitment that the foremost duty of the ambassador/representative of a ruler was to defend the honour of his master: $:^{14}$ he had to act as if the latter had been present in his person. In the seventeenth century it was still accepted that the emperor (and his ambassador) held the first rank among Christian powers but in the Catholic World he was just second to the pope (and his ambassador). However, below the level of the Emperor (and the King of Romans) there were endless debates about the ranking of rulers with regard to their precedence. "There was a general, though not complete, agreement that hereditary monarchs ranked above merely elective ones (in spite of the fact that Holy Roman Emperor was himself elected, at least in form) and that republics ranked lower than any kind of monarchy." ${ }^{15}$ Among the kingdoms there was a long quarrel for the first place between the King of France and the King of Spain. The French claim, however, could not be disputed from the 1660s on because of the strength of France: the monarch of Spain had to give

7 Ibidem, 74.

8 OSIANDER, 489.

9 Ibidem, 489.

10 WHALEY, 637.

11 HÖBELT, 27.

12 STURDY, 75.

13 Ibidem, 75.

14 ANDERSON, Matthew S.: The Rise of Modern Diplomacy 1450-1919, Abingdon-New York $1993,57$.

15 Ibidem, 59. 


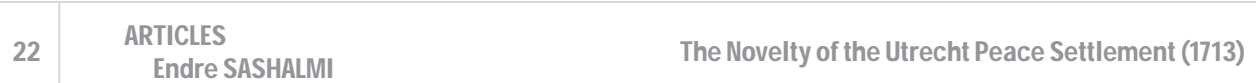

up his former pretension to pre-eminence. Debates over precedence were an inbuilt and enduring phenomenon of early modern diplomacy which proved to be a major problem in Westphalia.

This article, besides summarizing recent scholarship, relies on written primary sources (the Anglo-Spanish and the Anglo-French Treaties) ${ }^{16}$ and visual evidence too, and by combining the results it tries to enlist the new features of the Utrecht Settlement. The study of iconographic representation of peace conferences is a very recent phenomenon and it should not be neglected by political iconography. This approach has been fruitfully employed very recently in case of the Peace of Westphalia by Johannes Burkhardt. ${ }^{17}$ Analysing the $16^{\text {th }}$ $-17^{\text {th }}$-century iconographic depictions of Europe, such as the famous antropomorphic map known as Europa Regina, ${ }^{18}$ popularized mostly by Sebastian Munster's work (Cosmographia), he called attention to the new iconography of a German Flugzettel issued in 1648, announcing the Peace of Muenster. The engraving depicts a messenger on horseback spreading the news of the peace: "He is riding over a stylized map of Europe to Vienna, Paris and Stockholm. The map no longer depicts a universalist-hierarchical order, but rather the equality of the future European capital cities, by means of horizontal arrangements." 19 If the Westphalian Settlement itself did not, its visual representation mentioned here did have a new concept of European affairs.

In my article I will argue that the modern European state system came into being not with Westphalia but as a result of the Utrecht Peace Settlement. The Utrecht Settlement, "its genesis, and its aftermath is, however, far less studied and understood than its illustrious predecessor", despite the fact that, unlike Westphalia, Utrecht "brought stability to Europe for a substantial period of time".$^{20}$ Some comparisons between the two settlements will be inevitable but I intend to focus on the novelties brought on by Utrecht. Indeed, it was the treaty of Utrecht which "solidified many changes in diplomatic theory and practice". ${ }^{21}$ Strangely enough, these changes have not been listed so far taxonomically according to my best knowledge. I will concentrate exclusively on these aspects, and I do not discuss territorial changes with one exception. This is the case of Gibraltar, and the excuse for this exception is precisely the novelty of the argument on the basis of which Gibraltar was claimed by Great Britain.

16 https://en.wikisource.org/wiki/Peace_and_Friendship_Treaty_of_Utrecht_between_Spain_and_Great_Britain; https://en.wikisource.org/wiki/Peace_and_Friendship_Treaty_of_Utrecht_between_France_and_Great_Britain.

17 BURKHARDT, Johannes: Wars of States or Wars of State-formation, in: War, the State and International Law in Seventeenth-Century Europe, ASBACH, Olaf - SCHRÖDER, Peter (eds.), Farnham 2010, 17-34.

18 The map, Europa Regina, is an allegorical depiction of Europe conveying the hegemony of the House of Habsburgs.

19 BURKHARDT, 22

20 ONNEKINK, David: The Perplexities of Peace. Dutch Foreign Policy and the Religious Dimension of International Relations around 1700, in: Pax perpetua, SCHMIDT-VOGES, Inken - WESTPHAL, Siegried - ARNKE, Volker - BARTKE, Tobias (eds.), Münich 2010, 329.

21 MCCLURE, Ellen M.: Sunpots and the Sunkings. Sovereignty and Mediation in Seventeenth-Century France, Chicago 2006, 138. 


\section{Aspects of Novelty}

As the Utrecht Peace Settlement was, in fact, a series of bilateral treaties between the belligerent actors, to understand the aims and the measures of the settlement the starting point has to be the analysis of the operative parts of the treaties. Article II of the Anglo-Spanish Treaty is the best example in this respect because here the new terminology and principles emerge with great clarity:

"Whereas the war, which is so happily ended by this peace, was at the beginning undertaken, and was carried on for so many years with the utmost force, at immense charge, and with almost infinite slaughter, because of the great danger which threatened the liberty and safety all Europe, from the too close conjunction of the kingdoms of Spain and France; and whereas to take away all uneasiness and suspicion concerning such conjunction out of the minds of people, and to settle and establish peace and tranquillity of Christendom by an equal balance of power (which is the best and most solid foundation of a mutual friendship, and of a concord which will be lasting on all sides); as well the Catholic King ${ }^{22}$ as the Most Christian King ${ }^{23}$ have consented, that care should be taken by sufficient precautions, that the kingdoms of Spain and France should never come and united under the same dominion, and that one and the same person should never become the king of both kingdoms..." 24

\section{II.1. Europe-Christianity-balance of power}

Adam Watson called attention to the importance that the text of the treaty attributed to the concept of equilibrium, and he also noted the strong argument "against the disasters of a major war". ${ }^{25}$ These facts notwithstanding, it is crucial to underline in my view, that the terms liberty and safety of Europe, and balance of power occur as technical terms not only here but also in the other bilateral treaties: ${ }^{26}$ in fact, the latter was seen as the guarantee of the former. And although there are references in the treaties to the "peace of Christendom", and the invocation of the Trinity is also encountered, this religious phraseology was already anachronistic, ${ }^{27}$ masking the novel aspects of the settlement.

Indeed, it was in the treaties of Utrecht that the commonplaces of former peace treaties, such as Christianitas, respublica Christiana were used for the last time. ${ }^{28}$ On the other hand, it was for the first time that the expression "balance of power" entered into "formal

22 i.e. the King of Spain. The Spanish monarchs were given this title in 1494 by the pope as a reward for the conquest of Granada in 1492.

23 i.e. the King of France.

24 https://en.wikisource.org/wiki/Peace_and_Friendship_Treaty_of_Utrecht_between_Spain_and_Great_Britain. Italics are mine. (E. S.).

25 WATSON, Adam: The Evolution of International Society, London 1992, 199. Italics are mine. (E. S.).

26 OSIANDER, 120.

27 Ibidem, 110.

28 Ibidem, 110. 


\begin{tabular}{|c|c|c|}
\hline$\propto$ & 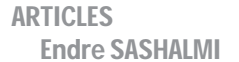 & 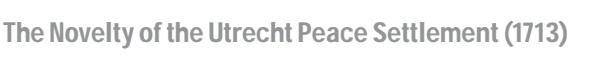 \\
\hline
\end{tabular}

diplomatic language". ${ }^{29}$ The emphasis is on the word formal (meaning that the term in question was included in a peace treaty for the first time), as it had been part of political thought and the vocabulary of statesmen long ago. The inclusion of balance of power into the text shows that by that time this notion was a "universally acknowledged" guideline for policy. ${ }^{30}$ Likewise, and not accidently, the term Europe definitely replaced Christendom in subsequent peace treaties. From this time on, in the peace treaties references were made to the maintenance or/and restoration of the balance of power in Europe. ${ }^{31}$

It is necessary to add at this point that the concept of the balance itself changed. Previously balance of power thinking was dominated by the bipolar model, or the so-called "adversorial balance", ${ }^{32}$ and therefore the libra provided the metaphorical reference for this view. Henry duc de Rohan in his treatise of 1638 (its English translation appeared in London, in 1641 under the title: "A Treatise of the Interest of the Princes and Christendome") wrote: "There be two Powers in Christendom which are as the two Poles, from whence descend the influences of peace and warre upon other States, to wit, the Houses of France and Spain." 33 By the time of the Utrecht settlement the concept of the so-called "associational balance of power" 34 , or "continuous mobile equilibrium" 35 had gained ground beside the libra-type, and the wording of the treaties reflected this view. The peace settlement was soon called the "la paix anglaise" 36 , and the most popular analogy to describe the type of balance of power that Utrecht created, was the solar system. In 1758 a British pamphleteer wrote: "What gravity or attraction, we are told, is to the system of the universe, that the ballance [sic] of power is to Europe." 37

\section{II.2. Divine right, hereditary claims, and the issue of formalities and precedence in 'international relations'}

When we use the term 'international relations' with regard to Early Modern Europe (14501789), we have to be aware of the fact that these relations were dominantly inter-dynastic relations and not so much inter-states relations as most polities were monarchies. Furthermore, the birth of the modern notion of state in the $17^{\text {th }}$ century did not result in the submerging of the person of the ruler in this abstract entity. Therefore, it took a long time until

29 THOMPSON, Andrew C.: Balancing Europe: Ideas and Interests in British Foreign Policy (c.1700-c. 1720), in: Ideology and Foreign Policy in Early Modern Europe (1650-1750), ONNEKINK, David - ROMMELSE, Gijs (eds.), Farnham 2011, 267.

30 ONNEKINK, 329.

31 FINNEMORE, Martha: The Purpose of Intervention: Changing Beliefs about the Use of Force, Ithaca 2003, 102

32 LITTLE, Richard: The Balance of Power in International Relations. Metaphors, Myths and Models, Cambridge 2007, 68.

33 ANDERSON, 154.

34 LITTLE, 67.

35 WATSON, 198.

36 Ibidem, 199.

37 ANDERSON, 167. 
the notion of the immortal and impersonal state gained priority against its mortal ruler. ${ }^{38}$ The Treaty of Utrecht, nevertheless, brought on important shifts. From the end of the $17^{\text {th }}$ century treaties concluded in the name of rulers were conceived as binding not only with regard to (the person of) the given rulers but also their successors. ${ }^{39}$ And it was also a novel phenomenon in the case of France that, unlike the Westphalian and other treaties, the Utrecht Treaty was not to be ratified by the Parlement of Paris. ${ }^{40}$

The Utrecht Settlement was characterized as the "success of the diplomats and of 'modern diplomacy'" ${ }^{41}$ This success was made possible by "the death of divine right kingship" 42 on the one hand, and the abandonment of the formerly almost endless and hair-splitting debates over ranks and precedence on the other. ${ }^{43}$ The "immensurable distance" between the diplomat and his ruler, whom the ambassador represented with the obligation as if the monarch himself had been present, collapsed: "This collapse is only made possible by abandoning the language of the divine source of kingly authority. Motivated not by transcendental legitimacy or essential right but rather by interest and passion, kingly decisions are open to debate and scrutiny. "44 Dynastic claims to territories and even to succession were overruled in the name of the balance of power in Utrecht. "Territory no longer resulted from a claim; a claim resulted from the demand for territory... Even the selection of the monarchs became a matter of strategic and diplomatic calculation... Matters of succession had become fully internationalized." 45

Closely related to this attitude was what Enrico Milano termed "the change in the history of the legal institution of conquest". ${ }^{46}$ He states: "The $18^{\text {th }}$ and $19^{\text {th }}$ centuries saw the development of norms regulating the way sovereignty could be transferred through the use of force. For instance the Treaty of Utrecht (1713) represented a turning point in the history of the legal institution of conquest, by requiring that the transfer of sovereignty would be legitimised by a peace treaty and not only by military occupation or annexation." 47 The author does not give an example but the case Gibraltar would confirm his view which was taken by the British in 1704. In the text of the Anglo-Spanish Treaty the article on Gibraltar $(\mathrm{X})$ does not mention any historical claim:

"The Catholic King does hereby, for himself, his heirs and successors, yield to the Crown of Great Britain the full and entire propriety of the town and castle of Gi-

38 WILSON, Peter H.: Absolutism in Central Europe, London 2000, 50.

39 DUCHHARDT, Heinrich: Peace Treaties from Westphalia to the Revolutionary Era, in: Peace Treaties and International Law in European History. From the Late Middle Ages to World War One, LESAFFER, Randall (ed.), Cambridge 2004, 47.

40 Ibidem, 48-49.

41 MCCLURE, 260.

42 Ibidem, 260.

43 STURDY, 75

44 MCCLURE, 260.

45 PHILPOTT, Daniel: Revolutions in Sovereignty. How Ideas Shaped Modern International Relations?, Princeton 2001, 91.

46 MILANO, Enrico: The Unlawful Territorial Situations in International Law, Leiden 2006, 102.

47 Ibidem, 102. 


\begin{tabular}{|c|c|c|}
\hline ate & 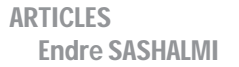 & 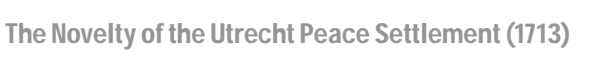 \\
\hline
\end{tabular}

braltar, together with the port, fortifications, and forts thereunto belonging; and he gives up the said propriety to be held and enjoyed absolutely with all manner of right for ever, without any exception or impediment whatsoever... And in case it shall hereafter seem meet to the Crown of Great Britain to grant, sell or by any means to alienate therefrom the propriety of the said town of Gibraltar, it is hereby agreed and concluded that the preference of having the sale shall always be given to the Crown of Spain before any others." ${ }^{48}$

Furthermore, "at the actual signing of the Anglo-British treaty at Utrecht on 13 July 1713 the British insisted that Gibraltar had been conquered by her [Queen Anne's] Arms" and therefore the treaty "did not give her title but only acknowledged what she had already" ${ }^{49}$ The article on Gibraltar is all the more interesting because, from time to time, it comes up in the recurrent debates about the status of Gibraltar between Great Britain and Spain. The debate on the interpretation of the article revolves around the term "property": "Spain insists that property is something less than sovereignty", while Great Britain insists that the cession "granted the British sovereignty over Gibraltar". ${ }^{50}$

By 1713 the system of states in Europe had become more integrated geographically and institutionally (permanent embassies on the basis of parity with professional staffs came into existence), and it began to function according to new principles. ${ }^{51}$ Legitimacy of participants was not deduced from tradition which had been so important in Westphalia but from reality: "rationality and not traditionalism" was the basis of the discourse..$^{22}$ Consequently, peace-making at Utrecht was not delayed or paralysed by formalities of rank and precedence: agreement was soon reached that formalities (e.g. who should sit where, or in which order the treaties should be signed) were to be put away during the time of negotiations. ${ }^{53}$ In the final stages the representatives "entered the meeting place of the town hall péle-mêle (i.e. without particular order)", and they sat at a round table which (having no head) avoided any claims of precedence. ${ }^{54}$ Even the emperor was no exception. The congress made only one minor concession to him: he was given a "place of honour in front of a great mirror". 55

There is one more aspect, in my view, related to the old system of ranking which, despite the suppression of the principle of rank and precedence during the negotiations, bears crucial importance for the Utrecht Settlement, namely the significance of the royal title as such. What I mean is the 'international' recognition of royal titles at a peace conference

48 https://en.wikisource.org/wiki/Peace_and_Friendship_Treaty_of_Utrecht_between_Spain_ and_Great_Britain.

49 Treaties of the War of the Spanish Succession. An Historical and Critical Dictionary, FREY, Linda S. - FREY, Marsha L. (eds.), Westport 1995, 185.

50 LINCOLN, Simon A.: The Legal Status of Gibraltar: Whose Rock is Anyway?, in: Fordham International Law Journal, 18, 1994, 1, 286-287 (footnote 10).

51 OSIANDER, 101-102.

52 Ibidem, 102-103.

53 Ibidem, 102-103.

54 ANDERSON, 66.

55 PHILPOTT, 91. 
for the first time. While there was no such recognition in Westphalia (though a new elector was added in the person of the Duke of Bavaria) there were two dynasties in these shoes in 1713. The title, "King in Prussia" had already been taken by Frederick III, Elector of Brandenburg, in 1701 (becoming thereby Frederick I) with the prior approval of the Emperor (in 1700): the title was not "King of Prussia", since Prussia was not a kingdom, and it was not part of the Empire. This title, however, remained dubious until it was recognized in the treaties in Utrecht. Frederick was able to achieve the recognition of this title in a treaty (11 April) with Louis XIV (the treaty, in fact, was signed soon after Frederick's death), "and the other powers followed suit implicitly by accepting that title in their treaties with Prussia". 56 This achievement made his son, Frederick William I (1713-1740), a full right member in an exclusive club of rulers. This provides a good example how ,international recognition' is to be understood and how it worked in practice.

The case of the ruling dynasty of Savoy was different from the Hohenzollern business, because the duke of Savoy got the royal title through the possession of the island of Sicily, given to him under the terms of the peace settlement, since Sicily had long been a kingdom. Though in 1720 Sicily was changed for Sardinia, the royal title remained. The gaining of royal title in 1713, at the same time, was the result of a long and carefully designed process by the Savoyard rulers. ${ }^{57}$

The Treaties of Utrecht meant an important milestone in the urge to acquire royal title because of what I termed the 'international' recognition of royal titles. The ambition of lesser powers in the $17^{\text {th }}$ century to acquire royal status was closely linked to the changing concept of sovereignty, and was part of a long process which deserves a fuller treatment. This was described by Edward Keene in the following manner: "The order of precedence was not...the only game in town. Between the sixteenth and eighteenth centuries it was coming under increasing pressure as new rising powers sought to improve their position within it. The traditional status order was under considerable challenge from the assertiveness of rising powers. Traditional sources of status, such as antiquity of lineage or title, began to be replaced by what one seventeenth-century author perceptively described as the role of fortune, and the 'continual revolutions' in the 'order of powers.'... The Savoyard search for a royal title, and what Heinz Duchhardt has called a 'wave of regalization' among German rulers, were all examples of how this process was beginning to escape the traditional authoritative controls of papal or imperial entitlement and points to the increasingly competitive and fluid nature of the ranking of princes in the early modern period." 58

There were two ways to reach the desired goal of royal status: there was, on the one hand, the so-called 'royal treatment' (trattamento regio), i.e. a distinguished treatment of the ambassador representing his/her ruler; on the other hand, there was a growing competition among uncrowned heads to acquire "territories carrying crowns" (i.e. territories which were kingdoms), ${ }^{59}$ or just titles without the real possession of the given territory. The House of

56 VERZIJL, Jan Hendrik Willem: International Law in Historical Perspective. (Vol. VI.), Leiden 1973, 168.

57 For this see especially STORRS, Christopher: War, Diplomacy and the Rise of Savoy 1690-1720, Cambridge 2000.

58 KEENE, Edward: International Hierarchy and the Origins of the Modern Practice of Intervention, in: Review of International Studies, 29, 2013, 5, 1086.

59 STORRS, 153. 


\begin{tabular}{|c|c|c|}
\hline$-\alpha$ & 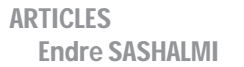 & 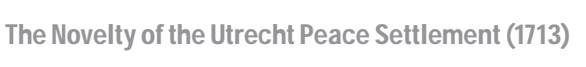 \\
\hline
\end{tabular}

Savoy employed both tactics from the early $17^{\text {th }}$ century onwards: in 1632 Victor Amadeus I "assumed the title King of Cyprus and the style of Royal Highness (Altezza Reale)", and, from time to time, the House of Savoy succeeded in getting ,royal treatment' during the $17^{\text {th }}$ century. ${ }^{60}$ But the final victory came only in 1713.

Royal title became important in the $17^{\text {th }}$ century not only because it was fancier than that of a duke. There was a distinction between the exclusive group of "crowned heads and the great number of uncrowned rulers", and the gap just was growing between them from the late seventeenth century onwards. ${ }^{61}$ Royal status was increasingly looked upon as a sign of full sovereignty, a kind of legitimating force for it.

A retrospective historical argument is also worth pondering as to the importance of the recognition of new royal titles. "A larger part than is sometimes admitted by those who disregard the 'antiquarian' study of International Law must be allowed to the effect of the kingly titles by Houses of Prussia and Savoy (recognized by all Europe in 1713) in securing that the unification of Germany and Italy respectively came through these two dynasties." ${ }^{2}$

\section{II.3. The new principles of the peace treaty in its engravings}

Were the new principles reflected in iconography? A Dutch engraving depicting and explaining the process of the conference, made by Abraham Allard, is eloquent in this respect. ${ }^{63}$ In the central (and the biggest) cassette of the engraving there is an inscription in Dutch and French, "The explanation of the emblem of Peace", with a verse in these two languages. The small cassettes below and on the two sides of the central one, show the process of the conference. The equality of negotiators of the rulers/states is clearly expressed by those cassettes which depict the negotiating parties as sitting at round- (or round-like) tables.

This engraving served as a model for an English language adaptation. (Figure 1.) The English engraving is called: "The Abstract of the Treaty of Peace and Commerce between the Queen of Great-Britain and the King of France concluded at Utrecht March 31/1713 April 11 ". Here the explanation of the allegory is missing, and the central part is identified by the following inscription: "An emblem of Plenty Peace and Traffic invented and Angraven [sic] by John Drapentier". The imagery of the central part is practically the same as in the other engraving. The main exception is that the importance of trade is represented here by many ships, in accordance with the inscription.

60 Ibidem, 153.

61 Ibidem, 153.

62 BUTLER, Geoffrey G - MACCOBY, Simon: The Development of International Law, New Jersey 2003, 33.

63 The location of the engraving: An informal explanation about the Utrecht treaty, online: http://www.meutrechtbarcelona.com/an-informal-explanation-about-the-utrecht-treaty/ (Downloaded 1. July 2015). 


\section{Figure 1. An engraving of scenes of the process of the Utrecht Treaty. John Drapentier, London, 1713}

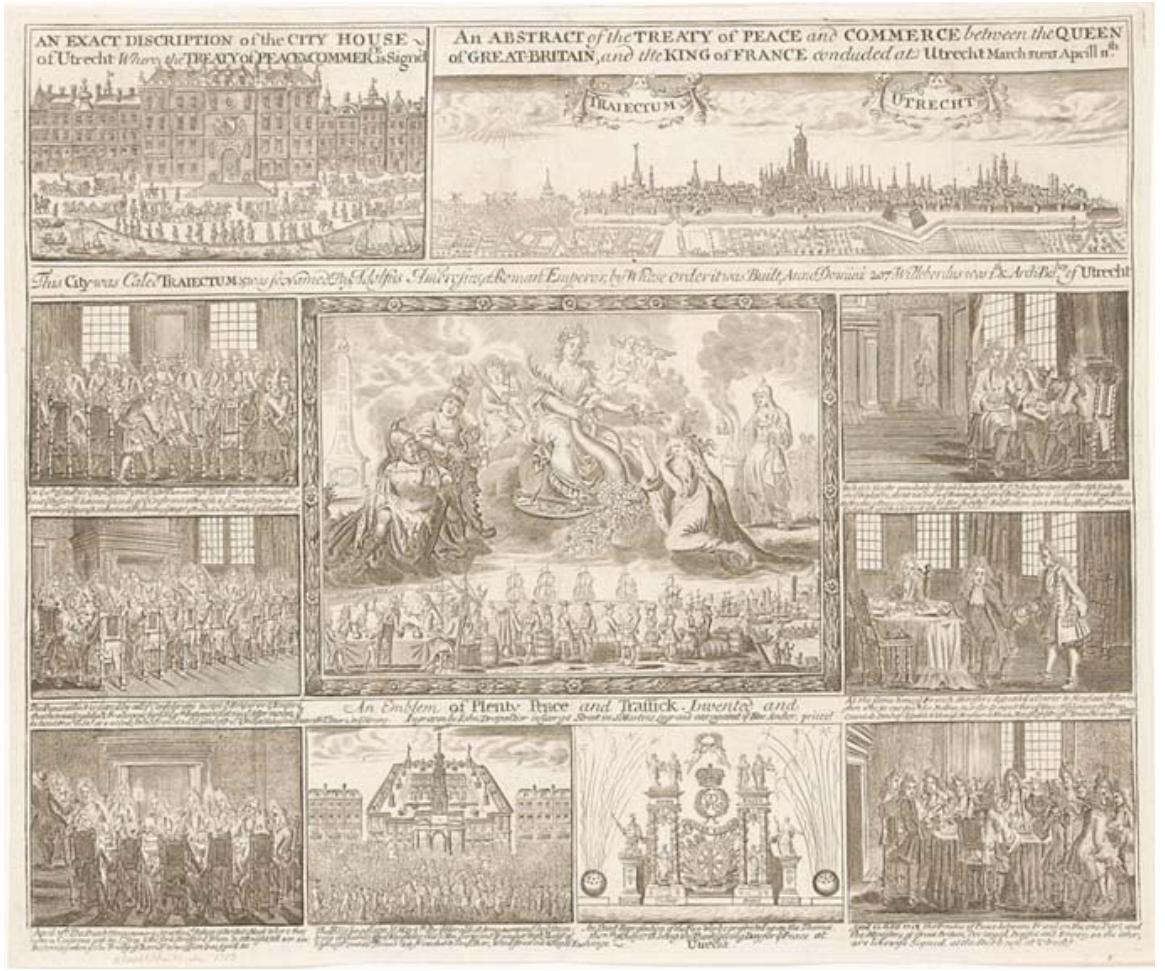

Source: http://www.geheugenvannederland.nl/?/nl/items/ RIJK04:RP-P-OB-83.361.

The woman in the middle, sitting on a globe and holding a horn of plenty in an upside-down position, is the allegorical representation of Peace: the flow of the blessing of peace is represented by the material goods pouring out of the horn of plenty. To the right of the allegory of Peace (in the upper part) there are two angels looking at her. The figure of Peace receives a crowned female figure on her knees, and the latter is given a branch of olive tree. This crowned woman is, no doubt, the allegorical representation of Europe as Queen, paying homage to the figure of Peace. On the left side of the figure of Peace we find the allegory of Justice with a sword in her one hand, and a libra in the other (allusion to the concept of "just balance"), while on the right side of the figure of Peace we find the allegory of Piety. The allegory of Piety is a combination of two representations of Piety offered by Cesare Ripa in his Iconologia. The dominant scheme is the description that Ripa attributed to Marcus Aurelius: i.e. a woman with a vessel for fumigation (called acerra by the Latins) in her hand; before her stands an altar (ornamented with flowers) with a burning sacrificial fire. ${ }^{64}$ The flame on the woman's head, however, comes from another version of the allegory of Piety offered by Ripa. 
Taken the three figures together, we have here the three virtues of good government around the allegory of Europe: Peace, Justice, and Piety. Pax, iustitia, pietas had long been the so-called 'Augustinian virtues' required of rulers - here they are seen as crucial to regulating 'international relations' in Europe. Finally, it must be added to the description that on the left side of the central part we can see the figure of Mars being tamed by Minerva. To sum up the visual message of the central scene: This section of the engraving is an adaptation of the theme called, Hercules and Minerva chasing/sending away Mars from Peace (and Prosperity) which was a popular theme in $17^{\text {th }}$-century political paintings. "When we think of a war deity, it is likely to be Mars, god of battle, rather than Minerva, goddess of war and wisdom. She represents strategic skills and calm victory. But he is a war lover who takes pleasure in conquest and crows in victory." 65

The verses of the bilingual engraving endorse my interpretation offered here; nevertheless, they provide just a partial explanation of the iconography of the central cassette. The verses call the Peace "a Woman-made Peace", coming from the land of angels, and this Peace is "remarkable and enriching the whole of Europe". The "taming of Mars" is attributed to the "balancing of the Netherlands/Dutch Union": therefore, the verses emphasize the role of the Dutch, and, at the same time, imply the personification of the United Provinces by Minerva. Mars was, of course, the bellicose Louis XIV.

The interpretation of the English engraving is somewhat different, as it is called a treaty between Great Britain and France, and it lacks an explanation by a verse. There is a good reason to identify the two mythological figures of the English engraving with the contemporary rulers of these states: consequently, Minerva here becomes the personification of Queen Anne of Great Britain. This kind of iconography was in line with Anne's contemporary British image which was characterised as follows: "Britain was at war for most of Anne's reign and it was therefore necessary to set her in martial pose." 66

\section{II.4. The language of diplomacy and of peace treaties}

As to the language used by diplomats during peace negotiations the Treaty of Utrecht represented a turning point. Probably Italian was "the commonest modern language in Europe in the second half of the $16^{\text {th }}$ century", yet, "it never became the accepted language of diplomacy" ${ }^{67}$ Beside Italian the importance of French was well on the way in the late $16^{\text {th }}$ and early $17^{\text {th }}$ centuries, and it undoubtedly became the dominant language of diplomacy in the second half of the $17^{\text {th }}$ century during the French age of greatness under Louis XIV - though not the language of the treaties themselves. For Latin survived longer as the language of the treaties "than as a language of negotiations": it was especially used in those cases "which involved a large number of states", or the principalities of the Empire. ${ }^{68}$ The Westphalian Treaties were written in Latin but during the negotiations besides Latin,

65 ELSHTAIN, Jean B.: Women and War, Chicago 1987, 173.

66 BLACK, Jeremy: Culture in Eighteenth-Century England: A Subject for Taste, London 2005, 31.

67 MATTINGLY, Garrett: Renaissance Diplomacy, New York 2009, 237.

68 ANDERSON, 100. 
Spanish, Italian, French "seem to have been indiscriminately used" .69 In Utrecht, however, the language of negotiations was definitely French. And some of the treaties too. "The Anglo-French treaty was in Latin (the British copy), as well as French (the French copy), but that of Rastatt in the following year in French alone ${ }^{\prime 70}$ despite the claim of the emperor who would have liked it in Latin.

Taken together all these aspects covered in my study, it is justified to state that not the Westphalian but the Utrecht Peace Settlement provided the guidelines for decision-makers which were to shape European affairs in subsequent peace conferences. Be it enough to mention that the territorial changes in the $18^{\text {th }}$ century, and the ones brought on by the Vienna Congress, were rationally calculated to maintain the balance of power in Europe.

\section{Abstract}

This article argues that the modern European states system came into being not with Westphalia (1648) but as a result of the Utrecht Peace Settlement (1713). Besides summarizing recent revisionist scholarship on the nature of the 'Westphalian order', the author tries to enlist the new features of the Utrecht Settlement which he considers the real turning point in the European inter-dynastic relations. He relies not only on written primary sources (the Anglo-Spanish and the Anglo-French Treaties) but also visual evidence to buttress this claim, and underlines the relevance of visual representation of peace conferences as an important field of political iconography.

\section{Keywords}

'Westphalian order', dynasticism, balance of power, importance of royal title, issues of rank and precedence, peace conferences in engravings

\section{References}

Peace and Friendship Treaty of Utrecht between Spain and Great Britain, online: https://en.wikisource.org/wiki/Peace and Friendship Treaty of Utrecht between Spain and Great Britain.

Peace and Friendship Treaty of Utrecht between France and Great Britain, online: https://en.wikisource.org/wiki/Peace and Friendship Treaty of Utrecht between France and Great Britain.

Peace and Friendship Treaty of Utrecht between Spain and Great Britain, online: https://en.wikisource.org/wiki/Peace and_Friendship Treaty of Utrecht between Spain and Great Britain.

Peace and Friendship Treaty of Utrecht between Spain and Great Britain, online: https://en.wikisource.org/wiki/Peace and Friendship Treaty of Utrecht between Spain and Great Britain.

69 Ibidem, 100-101.

70 Ibidem, 101. 
An informal explanation about the Utrecht treaty, online: http://www.meutrechtbarcelona. com/an-informal-explanation-about-the-utrecht-treaty/ (Downloaded 1. July 2015).

ANDERSON, Matthew S.: The Rise of Modern Diplomacy 1450-1919, Abingdon-New York 1993.

BLACK, Jeremy: Culture in Eighteenth-Century England: A Subject for Taste, London 2005.

BLACK, Jeremy: History of Diplomacy, London 2010.

BURKHARDT, Johannes: Wars of States or Wars of State-formation, in: War, the State and International Law in Seventeenth-Century Europe, ASBACH, Olaf - SCHRÖDER, Peter (eds.), Farnham 2010, 17-34.

BUTLER, Geoffrey G. - MACCOBY, Simon: The Development of International Law, New Jersey 2003.

DUCHHARDT, Heinrich: Peace Treaties from Westphalia to the Revolutionary Era, in: Peace Treaties and International Law in European History. From the Late Middle Ages to World War One, LESAFFER, Randall (ed.), Cambridge 2004, 45-58.

ELSHTAIN, Jean B.: Women and War, Chicago 1987.

FINNEMORE, Martha: The Purpose of Intervention: Changing Beliefs about the Use of Force, Ithaca 2003.

HÖBELT, Lothar: The Westphalian Peace: Augsburg Mark II or Celebrated Armistice?, in: The Holy Roman Empire 1495-1806, EVANS, Robert J. W. - WILSON, Peter H. (eds.), Leiden 2012, 19-34.

KEENE, Edward: International Hierarchy and the Origins of the Modern Practice of Intervention, in: Review of International Studies, 29, 2013, 5, 1077-1090.

LESAFFER, Randall: The Classical Law of Nations (1500-1800), in: Research Handbook on the Theory and History of International Law, ORAKHELASHVILI, Alexander (ed.), Cheltenham-Northampton 2011, 408-440.

LINCOLN, Simon A.: The Legal Status of Gibraltar: Whose Rock is Anyway?, in: Fordham International Law Journal, 18, 1994, 1, 285-331.

LITTLE, Richard: The Balance of Power in International Relations. Metaphors, Myths and Models, Cambridge 2007.

MATTINGLY, Garrett: Renaissance Diplomacy, New York 2009.

McCLURE, Ellen M.: Sunpots and the Sunkings. Sovereignty and Mediation in Seventeenth-Century France, Chicago 2006.

MILANO, Enrico: The Unlawful Territorial Situations in International Law, Leiden 2006, 102.

ONNEKINK, David: The Perplexities of Peace. Dutch Foreign Policy and the Religious Dimension of International Relations around 1700, in: Pax perpetua, SCHMIDT-VOGES, Inken - WESTPHAL, Siegried - ARNKE, Volker - BARTKE, Tobias (eds.), Münich 2010, 329-348.

OSIANDER, Andreas: The States System of Europe, Oxford 1994.

PHILPOTT, Daniel: Revolutions in Sovereignty. How Ideas Shaped Modern International Relations?, Princeton 2001.

RIPA, Cesare: Iconologia (Roma 1603), Budapest 1997.

STORRS, Christopher: War, Diplomacy and the Rise of Savoy 1690-1720, Cambridge 2000.

STURDY, David J.: Fractured Europe 1600-1721, Oxford 2002. 
THOMPSON, Andrew C.: Balancing Europe: Ideas and Interests in British Foreign Policy (c.1700-c.1720), in: Ideology and Foreign Policy in Early Modern Europe (1650-1750), ONNEKINK, David - ROMMELSE, Gijs (eds.), Farnham 2011, 267-282.

Treaties of the War of the Spanish Succession. An Historical and Critical Dictionary, FREY, Linda S. - FREY, Marsha L. (eds.), Westport 1995.

VERZIJL, Jan Hendrik Willem: International Law in Historical Perspective. (Vol. VI.), Leiden 1973, 168.

WATSON, Adam: The Evolution of International Society, London 1992.

WHALEY, Joachim: Germany and the Holy Roman Empire. Volume I: Maximilian to the Peace of Westphalia 1493-1648, Oxford 2012.

WILSON, Peter H.: Absolutism in Central Europe, London 2000. 